\title{
Weather-Related Metaphors in English and Arabic: A Contrastive Study
}

https://doi.org/10.33806/ijaes2000.21.1.1

\author{
Aya Abdulraheem and Shehdeh Fareh \\ University of Sharjah, UAE
}

\begin{abstract}
This study aims at identifying the similarities and differences between weatherrelated metaphors in English and Arabic in terms of structure, function, and range of collocations. A sample of English and Arabic weather-related metaphors was collected from bilingual and monolingual dictionaries in both languages and from relevant corpora such as COCA and BNC. In addition, weather-related metaphors were collected from everyday conversations, dialogues and talk shows in the two languages. The data analysis revealed that weather-related metaphors are reflections of human experiences as they express human emotions, attitudes, behaviors, traits, actions, reactions, and situations. It was also found that weather-related metaphors are much more abundant in English than in Arabic. Moreover, English metaphors showed more diversity in the use of parts of speech than Arabic metaphors did. Temperature metaphors are the most frequent weather-related metaphors in both Arabic and English.
\end{abstract}

Keywords: ice, rain, snow, temperature, weather metaphors

\section{Introduction}

Metaphor is a linguistic phenomenon and a literary device, which is common in all languages, yet it differs from one language to another. The importance of a metaphor stems from its power in conveying meanings through vivid and visual images. Such power adds beauty and texture to the text, in addition to improving comprehension and enhancing writing. For example, metaphors facilitate expressing abstract ideas including optimism, cordiality, and enthusiasm by comparing them to simpler notions such as weather phenomena (a sunny mood, a warm welcome, a hot baseball fan). The fact that metaphors are widespread in all languages and that they differ from one language to another calls for a cross linguistic study.

A metaphor can be defined as a figure of speech that establishes an implicit comparison between two seemingly unrelated items to highlight a common characteristic between them. Lakoff \& Johnson (2003) define metaphors as "understanding and experiencing one kind of thing in terms of another" (p. 5).

A metaphor is an implied comparison between two things that are mostly not alike, except in the aspect in which they are compared. For instance, in the metaphor "a foggy idea", the two main elements of the metaphor that are being compared , i.e. "fog", a weather element, and "idea", an abstract notion, share nothing but the characteristic in which they are compared, which is the idea of 
"vagueness". In other words, describing an idea as being foggy implies that this idea is as unclear and vague as fog. Otherwise, "fog" and "idea" are two different words with very different meanings and come from different semantic fields.

The concept of metaphors has captured the attention of many Arab linguists as well. Shaker (1988) defined a metaphor (isti?aarah) as "one sort of comparison where it measures what the heart feels and what the brain understands" (p.20). This emphasizes the role of a metaphor in the emotional impact on the listener by influencing his thoughts and feelings, which determines the ability of the metaphor to convey the intended message or draw the desired image.

In both English and Arabic, Metaphors are idiomatic expressions that have been no long used as ornamentation tools used to polish the text, as metaphors have become part of peoples' everyday language. Farghal and Mansour (2020) point out, "The bulk of idiomatic expressions in English and Arabic (as well as in other languages) may have started out as metaphorical expressions and have, over long periods of time, and due to extensive use, become part of everyday communication" (p.107)

There are three basic terms that, according to Richards (1965), have been commonly used to describe the components of a metaphor: tenor, vehicle, and ground or object, image, and sense as introduced by Newmark (1988a). The tenor represents what is described by the metaphor, the vehicle refers to the picture created by the metaphor and in terms of which the tenor is described, and the "ground" stands for the analogies established between the "tenor" and the "vehicle". These components are illustrated by the following examples from $\mathrm{Al}$ Murshid dictionary (2013) and Dictionary.com.

1) Inhimar addumu:

2) Tears rained from her eyes

Both examples share the same metaphor in the two languages. Using Richard's analytical model, addumu: ${ }^{c} /$ الدموع and 'tears' constitute the tenor, i.e. what is described by the metaphor; 'rain' is the vehicle, i.e. the notion to which 'tears' and addumu: ' الدموع are being compared, and inhimar / نعمار and 'rained from their eyes' are the ground, i.e. the sense according to which 'tears' and 'rain' are compared, which denotes abundance.

\section{Review of Literature}

Contrastive analysis is a subfield of linguistics that aims at comparing and contrasting two language systems or subsystems in order to identify the similarities and differenced between them (Al-Shukri and Fareh, 2017,163). A number of contrastive studies have compared and contrasted metaphors pertaining to various topics including food (Alsadi, 2017), business (Al Jumah, 2007), color (Barcelona and Soriano, 2004), and feelings (Prystupa, 2016). However, the topic of weather-related metaphors has barely been investigated.

A study was conducted by Żołnowska in 2011 to highlight the pervasiveness of weather-related metaphors that indicate the presence or absence of problems that humans face in their daily life. A significant claim of the study was that weather-related expressions reflect the experiential basis of life events. 
Weather metaphors drawn from the BNC have been divided into two groups: One describes good weather and expresses cheerfulness, and the other describes bad weather and evokes sadness and problems. Żołnowska's study concluded that metaphors are a part of the human conceptual system; thus, the structure of everyday communication reflects metaphorical thinking. Another conclusion of Żołnowska's study is that weather phenomena have been considered as problem indicators, and this conceptual structure is exhibited in everyday language. That is to say, people tend to use weather-related concepts metaphorically to express their life problems.

Another study was conducted by Valiuliene (2015) on temperature metaphors in Lithuanian and English. The purpose of Valiuliené's study was to identify temperature metaphors in the two languages and contrast them. The study concluded that the range of temperature metaphors in Lithuanian is wider than in English. Moreover, the two languages, Valiuliene infers, share a similar linguistic realization of temperature metaphors. However, certain differences were identified; verbs and adverbs are more frequent in Lithuanian, whereas English metaphors include more adjectival expressions.

Finally, Lorenzetti (2010) investigated the possible gaps in the temperature continuum in English and Italian. The data of the study have been culled from the British National Corpus (BNC), Corpus of Contemporary American English (COCA), and Italian Web Corpus (ItWac). The collected data were not limited to the central adjectives of hot, cold, cool, and warm, but they have also tackled 'peripheral terms', such as lukewarm, freezing, chilly, frosty, and tepid. Another significant aspect that was examined in this study was "the wide range of webbased and youth-coined terms which have emerged in the last few years based on temperature terms" (p.13). It revealed that "metaphor patterns which link the temperature domains to the realm of emotions are consistent cross-linguistically in British English, American English and Italian" (p.15). Moreover, a marked decrease in the differences in the metaphorical usage of these terms between British and American English was noted.

No study has been conducted to compare and contrast weather-related metaphors in English and Arabic. Therefore, the current study is expected to fill this gap in the field.

\section{Objectives}

The study aims at answering the following questions:

i. What similarities and differences exist between English and Arabic weather-related metaphors in terms of function, structure and collocation?

ii. What functions are weather-related metaphors used for in English and Arabic?

iii. What implications may such a study have for teaching translation and training translators? 


\section{Significance of the study}

The significance of this study lies in the fact that it may offer some important insights into the interaction between English and Arabic in the field of weatherrelated metaphors since each language uses different weather phenomena to express different life events. Moreover, having reviewed the literature, the researchers have not seen a single study yet that has been conducted on weatherrelated metaphors and compared them in English and Arabic. Therefore, the lack of studies in this field motivated the researchers to write this paper.

\section{Methodology}

\subsection{Data collection}

A total of 238 weather-related metaphors in English and Arabic were collected; 162 in English and 76 in Arabic. Collecting weather-related metaphors was not random. Rather, it has been based on the following criteria: First, the researchers have collected only those metaphors that are related to the selected weather phenomena. Second, all the selected metaphors have been collected from reliable sources. For example, the corpus of this research has been culled from bilingual and monolingual dictionaries, including Al-Murshid, Al-Mawrid, Al-Maany, Dictionary.com, and The Free Dictionary. In addition, relevant corpora such as COCA and BNC, websites, everyday conversations, dialogues and talk shows in both Arabic and English have been also used. Third, metaphors that constitute proverbs have been excluded because the scope of the study is limited to lexical metaphors only.

\subsection{Method of analysis}

Metaphors were first classified according to weather phenomena, and then, according to the functions of each metaphor. A corpus-based contrastive analysis of this lexical area was then carried out in an attempt to delineate possible common patterns of weather-related metaphors in English and Arabic, and establish possible gaps by drawing special attention to their structure, function, frequency, and range of collocations. The following steps were adhered to: collecting the English metaphors, collecting the Arabic metaphors, classifying each set of data into categories according to their functions, which have been extracted from the main theme of each metaphor, determining the linguistic structures in each set, identifying the collocations, and identifying similarities and differences between English and Arabic metaphors.

\section{Analysis and Findings}

Metaphors have been classified according to phenomenon and function. Twelve major phenomena have been identified including: precipitation (rain, hail, and snow), ice, fog and cloud, temperature, and other weather phenomena (seasons, sun and wind). However, the other weather phenomena (seasons, sun and wind) will not be discussed in detail in the current research due to space constraints. 
As for the classification of weather-related metaphors according to their functions, the researchers have been able to identify 33 main functions in both English and Arabic metaphors, under which many other sub-functions are subsumed. Below is a detailed explanation of the metaphors of each weatherrelated phenomenon in accordance with the function of each metaphor.

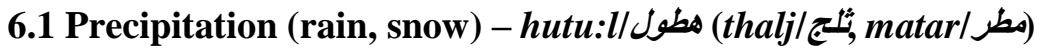 Rain in English metaphors}

The researchers noticed that all English rain metaphors fell into one functional category - 'abundance, profusion, continuity and succession.' For example, "to rain favors upon a person" means "to offer, bestow, or give in great quantity" (dictionary.com). It implies abundance of bestowals. Moreover, "tears rained down their eyes" implies how tears are like rain, which reflects the intensity of crying and sadness.

\section{Rain (matar) in Arabic metaphors}

Rain metaphors in Arabic are not limited to the use of the word "matar". Other terms and verbs of rain-related metaphors that indicate rain have also been used,

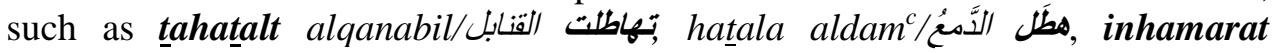

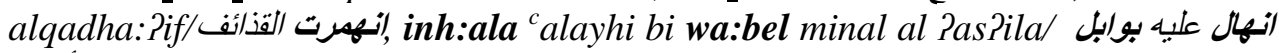

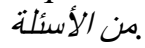

All the examples of Arabic rain-related metaphors found have been classified under the same functional category, which is expressing abundance, profusion, continuity and succession. For example, inhalat calayhi al PasPila/نهالت علبه الأسئلة indicates the vast number of questions addressed to him, and Pumtira bi wa:bil minal rasa:s indicates profusion, continuity and succession.

\section{Rain in English and Arabic metaphors}

It was found that both English and Arabic possess a limited number of rain metaphors. However, Arabic rain-metaphors seem to outweigh the English ones. Furthermore, all rain metaphors in both languages can be classified under the same functional category, which is "abundance, profusion, continuity and succession." However, certain asymmetries can be outlined between the two languages. For instance, unlike English, Arabic uses a variety of rain-related

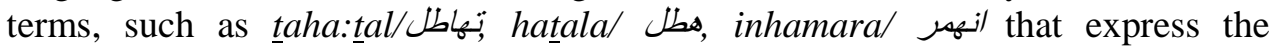
metaphorical meanings of the word rain other than the term matar/f مط itself. These verbs collocate with the noun "rain".

In terms of structure, rain-related metaphors in Arabic are mostly verb based. This is illustrated by the fact that in all the collected metaphors in Arabic, the weather phenomenon (matar) collocates with verbs, e.g., ?mtara/ مط

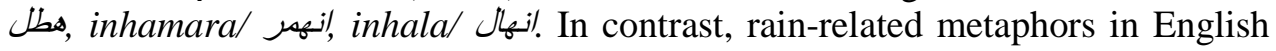
are a mixture between nominal and verbal phrases, and sentences. For instance, 
rain is used as a noun in the phrase a rain of blows, whereas shower is used as a verb in the expression shower someone with gifts.

Regarding collocations, it can be inferred that the term rain or the terms that indicate rain such as shower; wa:bil/بلونهر (نهر inhamara), whether they are nouns or verbs, collocate with both concrete and abstract terms in English as well as in Arabic, e.g., to rain favors upon a person; a rain of bullets; inha:lat calayhi al iqtiraha:t, inhamarat alqadha:?if, Pmtarahu bi kala:min qa:si, Pumtira bel qubula:t.

Furthermore, there are some metaphors which include the same collocations in both English and Arabic such as a hail of bullets and wa:bil minal rasa:s/g وائل sن الرصاص. However, there are some areas in which collocations in rain-related metaphors in English and Arabic are different. The words tears and dam $^{c} /$ dumu:c / دمع/دموع which collocate with the verb rain in English but with the

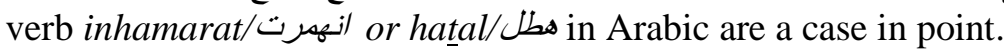

\section{Hail in English metaphors}

It has been found that all hail-related metaphors express abundance, profusion, continuity and succession. This is illustrated by the metaphor arrows hailed down on the troops as they advanced. This example implies that arrows fall in the same way that hail does, profusely and continuously. Another example that illustrates abundance is the plane hailed leaflets on the city.

The term hail in English hail-related metaphors occurs both as a noun, e.g., a hail of abuse, and as a verb, e.g., the plane hailed leaflets on the city and to hail criticism.

As for collocations, the term hail collocates with both concrete and abstract nouns, e.g., a hail of bullets and a hail of abuse.

\section{Hail in Arabic metaphors}

There are no hail metaphors in Arabic. This may be attributed to the fact that hail is a weather phenomenon that is not very common in the Middle East.

\section{Snow in English metaphors}

The analysis reveals that snow metaphors have three major functions. First, snowrelated metaphors can indicate negative traits such as deception as in all I heard for an hour was snow. Now, what's the truth?. Also, being snowed into believing everything means being deceived. Second, snow is well-known as a symbol of the color white as in describing white skin as being snowy. Third, the word snow can be used metaphorically to indicate an action. In such a case, it is used as a verb. For instance, to snow someone means to "make an overwhelming impression on" him/her (dictionary.com) as in the metaphor the view really snowed them.

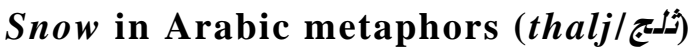

Snow-related metaphors have been somehow limited in Arabic, and they have two main functions. First, snow (thalj) stands as a sign of satisfaction and happiness. 


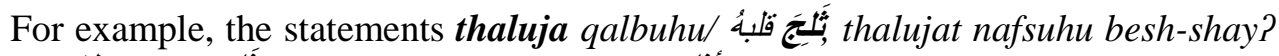

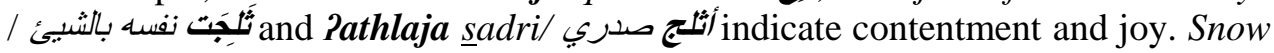
can also be used to reflect human relations. For instance, the statement dha:ba ath-thalj/ ذاب الثلـ indicates that tension is over, and relations are back to normal.

\section{Snow in English and Arabic metaphors.}

The findings reveal that snow-related metaphors in Arabic are more diverse and frequent than in English. This may be attributed to the fact that snow-related metaphors are often replaced by ice-related metaphors in Arabic. That is to say, ice-related metaphors are used more often and intensely than snow-related metaphors. For example, the verb 'tajammada'/تجمد, which is considered a verb of ice-related metaphors, is more frequently used than the verb '?athlaja' أثلج/in Arabic metaphors, as will be noticed below in the section on Arabic ice-related metaphors.

Snow-related metaphors in English express three main functions, namely indicating negative notions such as deception, e.g., she was snowed into believing everything (deceived); expressing colors, e.g., snowy skin; and actions such as leaving overwhelming impressions, e.g., the view really snowed them. On the other hand, Arabic snow-related metaphors express human feelings and relations,

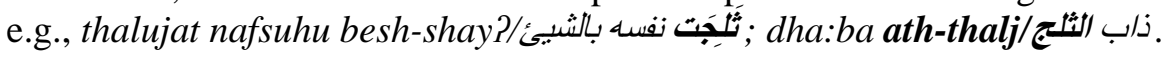

English snow-related metaphors have shown variation in structure and part of speech. For example, the word snow occurs as a noun, e.g., all I heard for an hour was snow. Now, what's the truth?; as a verb, e.g., you can try to snow me if you want, but I'm onto your tricks; and as an adjective, e.g., snowy skin.

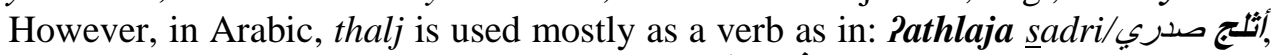
and just once as a noun in: dha:ba ath-thalj/اب الثلج.

In both English and Arabic, the word snow collocates only with concrete words, such as snowy skin; Pathlaja sadri/أثلج صدري.

\section{Ice in English metaphors}

Ice-related metaphors that have been collected in this paper were not limited to the use of the word ice to express its metaphorical meanings. In fact, other terms, such as thaw and freeze, which are closely related to the word ice, were also used. Metaphors of ice have several functions such as:

a) Expressing relations

One of the functions of ice-related metaphors is expressing relations. For instance, a thaw in relations between the two countries means an increase in friendliness or cordiality in the relationship, whereas relationships are frozen means that making growth or change is impossible.

b) Expressing attitudes and behaviors

Ice-related metaphors can also express attitudes and behaviors. For instance, the metaphor she thawed out sufficiently to allow a smile to appear indicates an attitude of 'cordiality'. In other words, it means that she became friendlier or more 
cordial. On the other hand, other ice-related metaphors express 'unenthusiastic, disdainful, or unfriendly attitudes' as in a freezing glance, or an icy contempt, gaze or voice. Other attitudes and behaviors such as 'reserve and formality' can also be expressed by ice-related metaphors as in the ice of his manner betrayed his dislike of the new ambassador. Besides these, ice can be an indicator of 'abandonment, unconcern, and indifference'. For instance, Bart iced Sam for obvious reasons means Bart ignored Sam, and everybody seems to be giving someone the freeze implies they are ignoring him/her. Therefore, freezing people indicates the act of ignoring them as in: Don't freeze me, gang! I use a mouthwash!

c) Expressing human feelings

Another function of ice-related metaphors is to express human feelings. For instance, for a person to be frozen indicates the feelings of embarrassment, fear, fright, horror, or terror.

d) Expressing situations

The term ice, metaphorically used, can express embarrassment: Don't ice me in front of my friends.

e) Indicating positive traits

Ice-related metaphors can express positive traits, such as excellence as in her answer was ice, which means that her answer was excellent.

f) Expressing lack of movement

To stop moving and hold perfectly still: The fuzz shouted, "Freeze, or you're dead meat!" 'Freeze' in this example means "to hold perfectly still" (The Free Dictionary).

g) Indicating crimes or violations

Metaphorically used, ice means 'bribe', e.g., a lot of those cops take ice; also, to ice someone means to kill him/her, e.g., the mobsters threatened to ice him if he went to the police.

h) Indicating arranging or signing agreements, or contracts

The statement "we'll ice the deal tomorrow" means "to settle or seal; make sure of, as by signing a contract" (Dictionary.com). Also, ice may express the act of "making a business arrangement more attractive by adding features or benefits" (Dictionary.com), e.g., the star pitcher wouldn't sign his new contract until the team iced it with a big bonus.

i) Meaning diamonds/jewels

That old dame has tons of ice in her hotel room (diamonds, jewels).

j) Expressing victory

Her second goal iced the game implies "establishing a winning score or insurmountable lead in or otherwise assure victory in a game or contest." (Dictionary.com).

\section{Ice in Arabic metaphors (jail:d/جليد)}

The study reveals that ice-related metaphors in Arabic have the following functions: 
a) Expressing relations

The term jail:d جليد/ ice) is sometimes used to describe a repaired state of relationships after tension. In other words, ice-related metaphors are often used in cases of conciliation in relations between groups of people or countries, as in the following examples:

- Badirfe kasril jali:d wa Pinha?il khila:f

$$
\text { باد في كسر الجلبي وأنهى الخلاف }
$$

- Yajib Pithabatil jail:d baynal tarafayn litahsi:nil cala:qa:t.

$$
\text { يجب إذابة الجلبي بين الطرفين لتحسين العلاقات }
$$

- Sa:datil cala:qa:t baynal dawlatayni ha:laton minal jumu:d.

سادت العلاقات بين الدولتبن حالة من الجيود.

b) Expressing reactions such as shock

In the statement tajammad ar rajulu fi: maka:nihi ${ }^{c}$ indama sami ${ }^{c}$ a khabara wafa:ti wa:lidihi تجمد الرجل في مكانه عند سماعه خبر وفاة والده the verb 'tajammada/تجد the (froze), which is the process of forming ice, is used metaphorically to describe the magnitude of the shock that dominated this man's reaction when he knew of his father's death. That is to say, the man did not have the ability to move, as if he had turned into ice, when he received the news of his father's death.

c) Indicating financial procedures such as controlling bank accounts

The verb "jamada" (freeze) is used metaphorically to express certain actions such as controlling money and bank accounts by preventing their disposal, as in the following two examples: jammadal hisa:ba:til bankiyya/ جمد الحسابات البنكبة jammadal ?amwa:l/ جمد الأموال

\section{Ice in English and Arabic metaphors}

It has been noticed that ice-related metaphors are much more frequent in English than they are in Arabic. This can be due to the diversity of fields in which English ice-related metaphors can be used. For example, ice-metaphors can express human feelings, emotions, attitudes, and traits. They can also be used to indicate violations and victory etc. On the other hand, the fields in which Arabic icerelated metaphors are used are limited: they can be used to express relationships, indicate certain reactions and can be useful in the field of banks and finance.

The term ice in English metaphors falls into all parts of speech. For instance, ice was used as a verb in we'll ice the deal tomorrow; as a noun in that old dame has tons of ice in her hotel room; and as an adjective in an icy contempt, gaze, shiver, or voice. However, the term jail:d appeared as a noun and as a verb

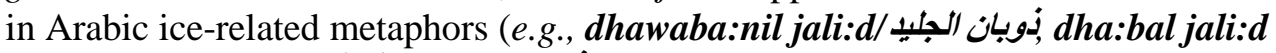
baynal dawlatayn/(ّ) اب الجليب بين الدولتين. No adjective form has been derived from this Arabic noun. Furthermore, the word ice has been used alone as a noun, as a verb or as an adjective in most English ice-related metaphors. In some examples, other ice-related terms like freezing, thawing, and frozen are used instead of ice. However, in Arabic, the word jali:d (ice) has not been used alone: it has been used either as a noun preceded by a verb or a noun that relates to ice (e.g., 
Pidhabatil jali:d/إذابة الجلبي), or has been replaced by verbs or nouns derived from the terms tajammada ,e.g., jammadatil Pamwa:l/جمت الأموال).

The findings clearly show that the functions of English ice-related metaphors are more diverse than those in Arabic, as they express relations, attitudes and behaviors, situation and status, positive traits, movements, crimes and violations, conventions, contracts and business, jewels, and victory. On the other hand, Arabic ice-related metaphors express relations, actions, and reactions.

The only common function between ice-related metaphors in the two languages is the expression of relations. In both languages, it has been inferred that thaw in relations / dhawaba:nil jali:d fil cala:qa:t/لوبان الجلبي في العلاقات implies an increase in friendliness or cordiality in the relationship and a decrease in tension and conflict; on the other hand, for relations to be frozen implies the exact opposite, e.g., Sa:datil cala:qa:t baynal dawlatayni ha:laton minal jumu:dبادت العلاقات بين الدولتنين حالة من الجمود

Furthermore, the findings reveal that the diversity of collocations of the word ice contributes to the diversity of its functions. In both languages, the word ice was used in a diverse set of collocations, which resulted in different meanings for the same word. For example, to ice a deal means to sign it; to ice a person means to kill him, embarrass him, or ignore him; to ice a game means to achieve victory in it. The same thing can be applied to the Arabic ice-related metaphors. For example, tajammadar rajul/تجمد الرجلmeans he could not move due to shock, while jummidatil hisa:ba:til bankiyya/جمدت الحسابات البنكية means that they were controlled and blocked. Therefore, the collocation of a word in a metaphor indicates the function of this metaphor and denotes its meanings.

However, the functions of a metaphor are not determined just by the collocations of the words, but also by the context in which the words are found. For instance, the metaphor to ice a person can imply three different meanings: to ignore this person, to embarrass him, or to kill him.

\subsection{Fog and Cloud (addaba:b wal ghuyu:m/الضباب والغيوم) Cloud in English and Arabic metaphors}

The researchers have found that cloud metaphors are more frequent in English than they are in Arabic. English cloud-related metaphors notably vary in their functions. First, they can express a state of mind as in cloudy thinking, which reflects a confused mind. Second, they express human emotions as in: worry clouded his brow, and his brow clouded with anger, which express the feelings of anxiety and anger. Third, the word cloud also indicates difficult and potentially problematic situations as in the event was clouded over by protests. Fourth, the term cloud can also indicate ignorance, e.g., a cloud of ignorance. Fifth, cloud metaphors can express disasters or destruction as in: The hardships of war cloud his childhood memories. Finally, the term cloud is metaphorically used to indicate the action of concealing or obscuring something, e.g., the smoke from the fire clouded the sun from view; don't cloud the issue with unnecessary details (to 
make it obscure). The only cloud-related metaphor found in Arabic was saha:ba minal huzzn/سحابة من الحزن, which obviously expresses human feelings of sadness.

In English cloud-related metaphors, the term cloud is used as a noun, e.g, cloud of ignorance; as a verb, e.g., worry clouded his brow; and as an adjective, e.g, cloudy thinking. On the other hand, it occurs only as a noun in Arabic as in

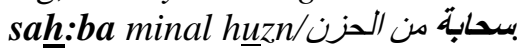

\section{Fog in English metaphors}

The analysis reveals that fog metaphors in English have three main functions. First, most of the fog-related metaphors in English tend to express a person's state of mind. For example, a foggy memory implies forgetfulness and confusion, a foggy idea implies vagueness, and to fog the mind expresses bewilderment. Further, the statement the debate did little else but fog the issue implies that the debate made the issue vague and more confusing, and in a fog implies that a person is "not fully aware or alert; having one's attention clouded with something" (Dictionary.com). Second, fog-related metaphors play a significant role in expressing human emotions. For example, the statement yes, I fogged up during the graduation ceremony implies " to become emotional and nearly cry over something" (The Free Dictionary). Finally, fog metaphors imply disinformation. For instance, the statement they shrouded their actions in a fog of disinformation implies that they gave misleading information to cover their actions as the fog covers the things around us.

\section{Fog in Arabic metaphors}

Fog metaphors in Arabic have several functions such as expressing vagueness, lack of clarity, and confusion, misleading or giving disinformation. For example, in the metaphor daba:bal jahl/ضباب الجكا, fog is used to express the effect of ignorance in making the vision of the brain foggy and making things as vague as fog in the air. Moreover, Pijaba daba:biyya/إبابة ضبابية indicates a misleading and

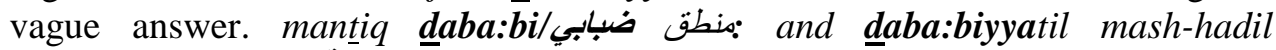
siya:si/ضبابية المشهر السياسي: indicate lack of clarity.

\section{Fog in English and Arabic metaphors}

The analysis shows that fog metaphors are frequent in both English and Arabic, and the most common function of these metaphors in both languages is indicating vagueness and confusion and being misleading, e.g., to fog the mind; marhala daba:biyya/برحلة ضبابية.

The structure of fog metaphors in English shows that the term fog is used as a noun (they shrouded their actions in a fog of disinformation); as a verb (to fog the mind); and as an adjective (my memory is a little foggy). On the other hand, the term fog occurs only as a noun and as an adjective in the Arabic fog metaphors, e.g, daba:biyyatil mawqif/:خبابية الموقف, mantiq daba:bi:منطق ضبابي. No verb form has been derived from this Arabic noun ( $\underline{d} \boldsymbol{a b a}: \boldsymbol{b})$. 
Another significant finding is that fog collocates only with abstract nouns in both English and Arabic fog metaphors, e.g., a foggy memory; to fog the mind; Pija:ba: daba:biyya/جابة ضبابية, mantiq daba:bi:/منطق ضبابي.

\subsection{Temperature darajatil hara:ra/ درجة الحرارة}

Metaphors related to temperature have been the most frequent among metaphors related to other weather phenomena. Temperature metaphors include metaphors of heat, warmth, coldness, coolness, and lukewarmness.

\section{Heat in English metaphors}

Heat metaphors express fourteen main functions.

First, the term heat is used in English as a reflection of a person's state of mind (forgetfulness, confusion, vagueness, bewilderment, excitement or optimism) and intensity. For example, having a hot temper indicates having intense or violent feeling. Moreover, to finish something while you are still hot expresses the mood of performing exceedingly well. Second, the term hot indicates the action of following something/someone closely, e.g., to be hot on the trail of a thief; in hot pursuit. Third, heat is used metaphorically to express colors too. For example, hot pink indicates the intensity of the color pink. Fourth, heat expresses the attitude of showing passion and lively feelings as in: a hot baseball fan. Fifth, it expresses feelings, e.g., a hot head indicates anger and a hot girl indicates sexual arousal. Sixth, heat metaphors are used to express situations and status, especially difficult and problematic situations as in: After his words, the room fell into a hot heavy silence. It also expresses illegal and dangerous situations as in a hot diamond necklace (stolen recently or otherwise illegal and dangerous to possess) or Lefty is hot because of his part in the bank job (wanted by the police). Seventh, heat-related metaphors indicate freshness or newness, as in hot (news/ stories/ topic/anthology). Eighth, they indicate importance, significance and demand priority too as in a hot tip/topic. Ninth, heat-related metaphors indicate popularity. For example, the Beatles were a hot group in the 1960 s indicates that this music band was popular and commercially successful. Tenth, a hot hand in sports expresses luck as in: A poker player has to have a hot hand to win the pot (extremely lucky). Eleventh, heat-related metaphors can be indications of positive traits, such as responsibility e.g., in the hot seat (in a position of responsibility) and skillfulness, e.g., a hot pitcher (playing well or winningly). Finally, heat-related metaphors have other functions such as expressing fun/absurdity, e.g., that's a hot one (funny joke), indicating good business, e.g., these things are really hot this season (selling well/ doing good business), and expressing intensity, e.g., the hottest battle of the war (violent, furious, or intense).

\section{Heat (hara:ra:/حرارة) in Arabic metaphors}

The concept of heat is used metaphorically in Arabic with five functions. First, it is used as an indication of certain attitudes and behaviors. For example, the 


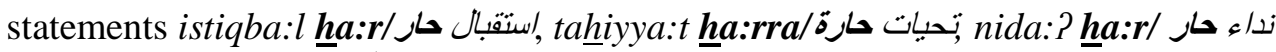
, and liqa:? ' لقاء حار/indicate an attitude of cordiality. Second, heat metaphors are a common way to express feelings in Arabic as in: hara:ratil masha:Pir/ حرارة جرارة العاطفة/and hara:ratil ca:tifa, heat metaphors can express a specific period of human life such as youth, e.g., hara:ratish shaba:b/حرارة الشباب, which suggests the rush of youth. Finally, heat is commonly used metaphorically in Arabic as an indication of intensity. For example, al-ha:r minal ${ }^{c}$ amal / الحار من العمل حر القتال/expresses the intensity of a hard work, and harull qita:l the fighting has intensified.

\section{Heat in English and Arabic metaphors}

English heat metaphors are more frequent than the Arabic ones. Moreover, the functions of English heat metaphors are more diverse; they express a state of mind, the act of following something/someone closely, colors, attitudes and behaviors, emotions, situations and status, importance/significance, popularity, luck, positive traits, and intensity. On the other hand, Arabic heat metaphors have just five main functions, which are expressing attitudes and behaviors, feelings/ emotions, intensity, and continuity and succession. It is worth mentioning that there are some common functions between English and Arabic heat metaphors, such as expressing attitudes and behaviors, feelings/emotions, intensity, and continuity and succession.

It can be observed that the concept of heat is expressed in English heat metaphors by using only the adjective hot, e.g., in the hot seat, a hot tip, too hot to handle: It is not used as a noun nor as a verb. On the other hand, the parts of speech in the Arabic heat metaphors are more diverse: the term hara:ra حرارة/(heat) is used as a noun, e.g., hara:ratil masha:Pir/حرارة المشاعر, as a verb, e.g., harull qita:l/ حر القتال جار (شديد)

\section{Warmth in English metaphors}

The study reveals ten functions of warmth metaphors in English. First, most of the warmth metaphors tend to express feelings and emotions. For example, to become warm when contradicted expresses anger. In addition, sometimes, to warm someone means to fill him/her with strong feelings of anger or zeal, e.g., restrictions had warmed the crew to the point of mutiny. On the other hand, a warm feeling expresses a good, pleasant, or friendly feeling as in it warms my soul to hear you say that. Warmth can also be metaphorically used to indicate contentment as in his cosy reception in America would have spread a warm glow back home. Further, having friendly, kind or sympathetic feelings towards someone can be expressed by warmth metaphors, e.g., my heart warms toward him. Second, warmth metaphors can express relations, for instance, warm friends means intimate friends. Third, some attitudes and behaviors can also be expressed by warmth metaphors: cordiality as in a warm smile; a warm welcome; a warm handshake: enthusiasm as in the speaker quickly warmed to her subject: and 
passion and liveliness as in a warm heart; warm interest. Fourth, warmth metaphors can also indicate the intensity of colors, e.g., warm colors look good on most skin tones. Fifth, inconvenient situations can be indicated by warmth metaphors, for example, his opponents made things so warm that he decided to quit (uncomfortable or unpleasant). Finally, there are other functions for warmth metaphors, such as expressing vitality, e.g., a warm debate (animated, lively, brisk, or vigorous), freshness, e.g., a warm scent (strong or fresh), and intensity, e.g., the racial situation was warming up.

\section{Warmth in Arabic metaphors}

The Arabic warmth metaphors collected are limited, and they have two main functions, which are expressing feelings, as in: difril masha: ${ }^{c} i r / 2$ دفئ الدشاعi and expressing cordiality, e.g., 'ina:q da:fi?l عناق دافئ; da:fir/قلب دافئ

\section{Warmth in English and Arabic metaphors}

Warmth metaphors are more frequent in English than they are in Arabic. There are two common functions between warmth metaphors in English and Arabic, namely, expressing feelings and attitudes of cordiality. As for the structure, the concept of warmth was expressed as verbs and adjectives in English metaphors, e.g., my heart warms toward him, and a warm feeling. However, it was used as

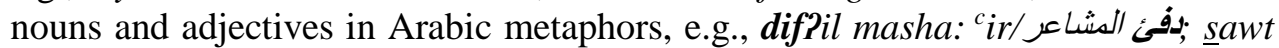
da:fir/صوت دافئ. It is worth mentioning that the range of collocations in English warmth metaphors are wider than they are in Arabic, as warmth collocates with both concrete, and abstract nouns in English, e.g., warm friends and a warm smile, whereas it collocates only with abstract nouns in Arabic, e.g., s sawt da:fir/ عناق دافئilina: However, it has not escaped our notice that even in English metaphors, warmth collocations with abstract nouns as in $a$ warm feeling; a warm smile; it warms my soul; and a warm welcome overweigh warmth collocations with concrete nouns.

\section{Coldness in English metaphors}

The data analysis of cold metaphors in English revealed that they have five different functions. First, cold metaphors tend to express controlled feelings, as in: there was a cold anger in his voice, which indicates controlled emotions of anger, and they express lack of emotions also. For example, the statement apparently, she's sexually cold reflects the lack of sexual feelings. Second, cold metaphors can indicate the general atmosphere of places. For example, the statement the cold atmosphere of a hospital waiting room indicates depression, and the statement the school was a cold, unwelcoming place indicates dullness. Third, certain attitudes such as unenthusiastic, disdainful, or unfriendly attitudes can be expressed by cold metaphors, as in: he gave me a bright cold stare. Fourth, cold can be used metaphorically to imply hostility as in: she would never feel welcome in this city with its cold, unsmiling inhabitants. Finally, coldness can be related to wars also, 
as in the cold war, which is a "conflict over ideological differences carried on by methods short of sustained overt military action and usually without breaking off diplomatic relations" (Merriam Webster).

\section{Coldness in Arabic metaphors}

The researchers have found six main functions for coldness metaphors in Arabic. First, coldness in Arabic tends to express negative traits, such as dispassion, e.g., jadda fil Pamri thumma barad/جد في الأمر ثم برد, baradat himmatuhu/بردث هنته and weakness, e.g., Panta hujja ba:rida finniqa:sh/weak argument). Second, coldness in Arabic indicates unenthusiastic, disdainful, or unfriendly attitudes as in: sala:m ba:rid/سنقال بارد/2 istiqba:l ba:rid. Third, coldness metaphors in Arabic indicate dullness. For example, nukta ba:rida/ بكتة باردارد indicates a silly joke with no emotions, and khita:b ba:rid/_نطاب باردة indicates a dull speech. Fourth, coldness has to do also with the lack of feelings, as in:

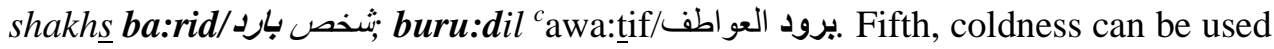
metaphorically to indicate mitigation, e.g., barradal Palam/ برد الألم Finally, coldness metaphors tend also to express the reaction of composure and calmness, e.g., Pinsa:n ba:rid / ba:ridal tabc إنسان بارب/بارد الطبع.

\section{Coldness in English and Arabic metaphors}

Unlike other temperature metaphors, Arabic coldness metaphors are more frequent than English ones. Arabic coldness metaphors have six main functions, namely expressing negative traits (dispassion and weakness), unfriendly attitudes, dullness, lack of emotions, mitigation, and composure or calmness. On the other hands, English coldness metaphors have five main functions, namely expressing controlled feelings, lack of emotions, unfriendly attitudes, hostility, and indicating the atmosphere of places (dullness and depression) and war. Noticeably, the two common functions between English and Arabic coldness metaphors are expressing lack of emotions and unfriendly attitudes.

As for structure, the parts of speech in Arabic were more diverse, with the concept of coldness occurring as a noun, e.g., buru:dil cawa:tif/برود العواطف, a verb, e.g., baradat himmatuhu/بردت هيته and an adjective, e.g., istiqba:l ba:rid/ستقبال بارد. On the other hand, coldness in English metaphors occurred only as an adjective, e.g., cold anger; cold war.

Regarding collocations, coldness in both English and Arabic metaphors collocates with abstract nouns, e.g., khita:b ba:rid;هاب

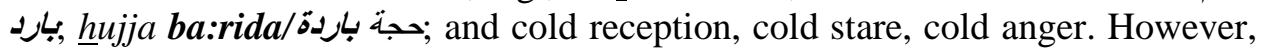
there are some exceptions where coldness collocates with concrete nouns, namely people or places, e.g., a cold person, the school is cold, cold inhabitants; and

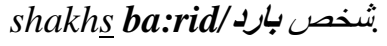




\section{Coolness and Lukewarmness}

Our results have demonstrated that coolness and lukewarmness English metaphors are the only temperature-related metaphors that have no equivalents in Arabic.

\section{Coolness metaphors in English}

Coolness metaphors have seven main functions, which branch out to secondary ones. First, they indicate the reactions of composure and calmness. For example, to remain cool in the face of disaster reflects composure, and if a person strove to be cool while someone is crying, it implies that he is calm and not heated by passion or emotion. Second, coolness may indicate deliberate actions, e.g., a cool and calculated action. Third, some attitudes and behaviors can be expressed by coolness metaphors. For example, a cool reception, a cool reply to an invitation, and a cool glare, look, smile, voice or welcome express unenthusiastic, disdainful, or unfriendly attitudes. Also, coolness can reflect attitudes of indifference and abandon, e.g., he was cool to her passionate advances. Fourth, coolness metaphors can also be a reflection of the lack of feelings, for example, she likes to play it cool implies that she is dealing with the issue emotionlessly. Fifth, coolness metaphors can express satisfactory and unproblematic situations, e.g., it's cool with me (unproblematic); if you want to stay late, that's cool (acceptable; satisfactory). Sixth, coolness can be used metaphorically to indicate positive traits, such as elegance, excellency, and greatness, e.g., he is super cool (elegant and classy); this marketing company is always coming up with cool ways (excellent). Another positive trait that can be indicated by coolness metaphors is social etiquette, e.g., it's not cool to arrive at a party too early (socially adept). Finally, coolness can be an indication of negative traits also. For example, a cool lie implies audacity and impudence.

\section{Lukewarmness metaphors in English}

lukewarmness metaphors in English express four main functions. First, they may express reactions, as in: a lukewarm reaction that expresses lack of enthusiasm. Second, they can imply support, as in a lukewarm review. Third, lukewarmness can be also related to relationships as in a lukewarm relationship that expresses a relationship that is neither hot nor cold, but it is closer to being cold somehow. Finally, lukewarmness metaphors can indicate disdainful or unfriendly attitudes, as in a lukewarm (look/reception).

\section{Summary of major findings}

The study reveals the following:

1. Weather-related metaphors are reflections of human experience, as in both Arabic and English they express human emotions, attitudes, behaviors, traits, actions, reactions, situations, state of mind, and many other human experiences. 
2. Temperature metaphors are the most frequent weather-related metaphors in both Arabic and English. They represent $46 \%$ of the total weatherrelated metaphors.

3. Some weather-related metaphors recorded high frequency in English while they were very scarce in Arabic, as is the case in snow-related metaphors. This may be attributed to the fact that snow-related metaphors are often replaced by ice-related metaphors in Arabic since snow does not fall from Arabia's skies but water freezes into ice in cold desert nights. Consequently, ice-related metaphors are more frequent than snow-related metaphors. For example, the verb 'tajammada', which is considered a verb of ice-related metaphors, is much more frequent than the verb "Pathlaja" in Arabic.

4. Metaphors of a certain weather phenomenon may have more than one function. For instance, cloud-related metaphors may express emotions, states of mind, problematic situations, ignorance, disasters and destruction. A certain function may also be served by more than one weather phenomenon. A case in point is the metaphor cloud of ignorance, and daba:bal jahl / ضباب الجطل.

5. A metaphor of a certain weather phenomenon may have more than one meaning. Determining the appropriate meaning depends mainly on its collocations. For example, to ice a deal means to sign it; to ice a person means to kill him, embarrass him, or ignore him; to ice a game is to win it. The context in which the metaphor is found is fundamental to its meaning.

6. Structurally, English metaphors show more diversity in parts of speech than Arabic metaphors do. In English, weather-phenomena phrases have been used metaphorically as verbs (e.g., to fog, to ice, to rain), nouns (a cloud of, rains of, a storm of), and adjectives (snowy, sunny, hot, warm, cold). In contrast, weather-related metaphors in Arabic express weather

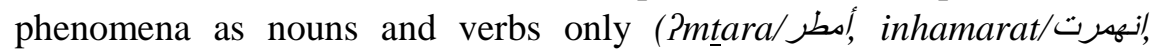

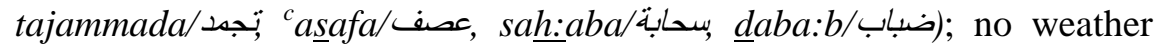
phenomenon, aside from temperature, has been used as an adjective, which will be explained later. Moreover, rain-related metaphors in Arabic are mostly verb-based. This is illustrated by the fact that in all rain metaphors in Arabic the word rain is mostly used as a verb, i.e.

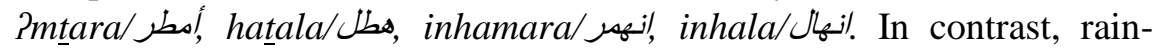
related metaphors in English are a mixture of noun and verb phrases, and sentences. For instance, rain is used as a noun in the phrase a rain of blows, whereas shower is used as a verb in the sentence showered someone with gifts.

7. Some metaphors such as a hail of bullets and wa:bel minal al Pas?ila/ وابل والبتسامة مشرقة/include the same collocations in both English and Arabic. However, collocations 
in other metaphors differ. For instance, the words tears; dumu: ${ }^{c} / d a m$ بـallocate with the verb rain in English, but with the verb

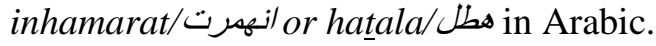

8. Although each phenomenon has different functions, one of these functions is usually predominant amongst all. The predominant function of a weather-related metaphor is identified for two main reasons: First, it is the function that is closest to the nature of the weather phenomenon. For example, expressing abundance and continuity is the predominant function of rain-metaphors, since rain itself is abundant in its nature and falls in a continuous way. Table (1) below displays the most prominent function of each weather metaphor in Arabic and English.

Table 1: Predominant functions of weather related metaphors

\begin{tabular}{|l|l|l|}
\hline $\begin{array}{l}\text { Weather } \\
\text { phenomenon }\end{array}$ & in English & in Arabic \\
\hline Rain & abundance and continuity & abundance and continuity \\
\hline Snow & deception & happiness and satisfaction \\
\hline Ice & $\begin{array}{l}\text { attitudes and behaviors + } \\
\text { relations }\end{array}$ & relations + reactions \\
\hline Fog & confusion & confusion \\
\hline Cloud & anxiety and distress & anxiety and distress \\
\hline Temperature & attitudes + emotions & attitudes + emotions \\
\hline Sun & cheerfulness & cheerfulness \\
\hline Wind & abundance and indifference & change \\
\hline
\end{tabular}

9. The findings of this study provide useful pedagogical implications for translation students, teachers, and translators. This study may represent a good guide to produce a fluent and idiomatic language, and reduce the incidences of error in translations.

\section{Conclusion}

To sum up, weather-related metaphors are reflections of human experience, feelings, values, practices, attitudes, situations, etc. Weather-related metaphors are more frequent in English than in Arabic. This could be attributed to the fact that climatic phenomena in the Western world are more diverse than in the Arab 
world. In this study, weather-related metaphors were discussed in relation to their function, connotation, and structure. A metaphor of a certain weather phenomenon may have more than one function; similarly, a certain notion may be expressed by metaphors of different weather phenomena. Moreover, the diversity of meanings and functions that a metaphor of a certain weather phenomenon may have can be attributed to the diversity of the collocations of this metaphor. Finally, each weather phenomenon has one predominant function that is closest to the nature of the weather phenomenon, and it is usually the most frequent function that the metaphor may have.

\section{Limitations of the study}

The data of this paper are limited to lexical weather-related metaphors only. Weather-related metaphors that constitute idioms have been excluded from the research due to practical constraints. The following examples illustrate some of these idioms: to be under the weather (feeling unwell); to save for a rainy day (to reserve something, especially money, for use in times of difficulty, trouble, or need.); to roast snow in a furnace (to attempt a futile, often ridiculous, task); to break the ice (to do something as a means of reducing or eliminating shyness, awkward tension, or unfamiliarity); every cloud has a silver lining (every negative situation has the potential to result in or produce something positive or beneficial);

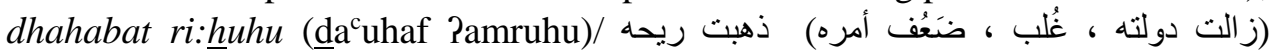

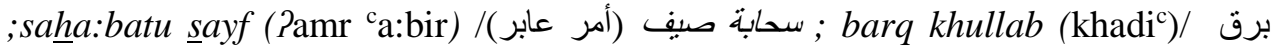
لخب(خادع). Moreover, some weather phenomena such as seasons, the sun and wind have not been discussed in detail in the current research due to space constraints.

Table 2: Transliteration symbols for Arabic vowels and some consonants

\begin{tabular}{|c|c|c|c|}
\hline Arabic alphabet & Symbol & Example & Meaning \\
\hline 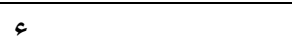 & $?$ & Pamal & hope \\
\hline 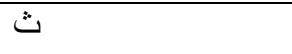 & th & tha'lab & fox \\
\hline ج & $\mathrm{j}$ & jamal & camel \\
\hline$\tau$ & $\underline{\mathrm{h}}$ & hub & love \\
\hline$\dot{\tau}$ & $\mathrm{kh}$ & khubz & bread \\
\hline$\dot{j}$ & $\mathrm{dh}$ & dhahab & gold \\
\hline j & $\mathrm{z}$ & zayt & oil \\
\hline
\end{tabular}




\begin{tabular}{|c|c|c|c|}
\hline ش & sh & shams & sun \\
\hline ص ص & $\underline{\mathrm{s}}$ & sayf & summer \\
\hline ض ض & $\underline{\mathrm{d}}$ & dayf & guest \\
\hline b & $\underline{\mathrm{t}}$ & tí:n & mud \\
\hline ط & $\mathrm{TH}$ & THuhr & noon \\
\hline$\varepsilon$ & c & cabd & slave \\
\hline$\dot{\varepsilon}$ & gh & gharb & west \\
\hline ق & $\mathrm{q}$ & qalam & pencil \\
\hline وَ & $\mathrm{w}$ & ward & rose \\
\hline يَ & $\mathrm{y}$ & yawm & day \\
\hline (فتحة) & $\bar{a}$ & kataba & he wrote \\
\hline (ضمة) & $\mathrm{u}$ & kutub & books \\
\hline (كسرة) - . & $\mathrm{i}$ & $\sin$ & tooth \\
\hline مد طويل اى & a: & ka:tib & writer \\
\hline ضمة طويلة و & u: & fu:l & beans \\
\hline كسرة طويلة ي & i: & fi:1 & elephant \\
\hline \multirow{2}{*}{$\begin{array}{l}\text { (أصوات علة مركبة) } \\
\text { Diphthongs }\end{array}$} & aw & mawt & death \\
\hline & ay & bayt & house \\
\hline
\end{tabular}

Aya Abdulraheem

University of Sharjah

Email: u16200782@sharjah.ac.ae

Shehdeh Fareh

College of Arts, Humanities, and Social Science

English Language and Literature

University of Sharjah

ORCID Number: 0000-0002-1196-9250

Email:shfareh@sharjah.ac.ae 


\section{References}

Abu-Saydeh, Abdul-Fattah S. (2013). Al-Murshid: A general Arabic-English Dictionary. Amman: Dar Al-Sharq Wa L-Gharb for Publishing and Distribution

Al Jumah, Fahad H. (2007). A comparative study of metaphor in Arabic and English general business writing with teaching implications (Doctoral dissertation, Indiana University of Pennsylvania). Retrieved from https://www.academia.edu/8766371/A_COMPARATIVE_STUDY_OF_M ETAPHOR IN ARABIC AND ENGLISH GENERAL BUSINESS WR ITING_WITH_TEACHING_IMPLICATIONS(Retrieved on 24 October, 2019).

Al Rasbi, Wedad. (2015). Translation of metaphors from Arabic to English: Selected medieval poems from the pre-Islamic era. (Doctoral dissertation, Indiana University of Pennsylvania). Retrieved from https://www.researchgate.net/publication/320486993_Translation_of_Meta phors_from_Arabic_to_English_Selected_Medieval_Poems_from_the_PreIslamic_Era (Retrieved on 24 October, 2019).

al-Ba'labakkī, Munīr. (1999). Al-Mawrid qāmūs anklizi-arabi: Al-Mawrid, a modern English-Arabic dictionary. Beirut: Dar el-Ilm Lil-Malayēn.

Almaany dictionary. https://www.almaany.com/ (Retrieved on 20 October, 2019).

Alsadi, Hanan Z. (2017). 'English and Arabic metaphorical conceptualization of food: a contrastive study'. Arab World English Journal for Translation and Literary Studies, 1(1), 112-126. doi:10.24093/awejtls/vol1no1.8

Al-Shukri, Shyma, \& Fareh, Shehdeh (2017). 'English 'Green'and its Arabic Equivalent 'Akhdar': Similar or Different?' International Journal of Arabic-English Studies, 17 (1), 163-182.

Barcelona Antonio \& Cristina Soriano. (2004). 'Metaphorical conceptualization in English and Spanish'. European Journal of English Studies, 8, (3), 295-307.

Dictionary.com. Retrieved from https://www.dictionary.com/(Retrieved on 25 October, 2019).

Farghal, Mohammed \& Mansour, Raneen (2020). 'Translating Arabic Metaphorical Expressions into English: Mahfouz's Morning and Evening Talk as an Example'. International Journal of Arabic-English Studies, 20 (1), 105-124.

Lakoff, George, \& Johnson, Mark (2003). Metaphors we live by. Chicago: University of Chicago Press.

Lorenzetti, Maria I. (2010). 'Temperature terms and their metaphorical usages in English and Italian: a contrastive study'. In 34th LAUD International Symposium Cognitive sociolinguistics: language variation in its structural, conceptual and cultural dimensions (pp. 585-604). 
Newmark, Peter. (1988). Approaches to Translation. London and New York: Prentice Hall.

Prystupa, Vitalii. (2016). 'Conceptual metaphors of anger in Chinese and English: a contrastive analysis'. Научный результат. Серия «Вопросы теоретической и прикладной лингвистики», 2 (3).

Richards, Ivor A. (1965). The Philosophy of Rhetoric. New York: OUP, (p. 144).

Shaker, Mohammed M (1988). Secrets of Eloquence. Egypt: Al Madani Publishing Press and Saudi Arabia: Dar Al Madani.

The Free Dictionary. https://www.thefreedictionary.com/ (Retrieved on 25 October, 2019).

Valiulienė, Edita. (2015). 'Temperature metaphors in Lithuanian and English: contrastive analysis'. Verbum, 6, 207-219.

Żołnowska, Izabela. (2011). 'Weather as the source domain for metaphorical expressions'. AVANT. Pismo Awangardy Filozoficzno-Naukowej, (1), 165179. 